\title{
ÜBER DIE FARBEN \\ KÖNIG RICHABDS II VON ENGLAND IN IHRER BEZIEHUNG ZUR CHAUCERDICHTUNG.
}

FINE HERALDISCHE STUDIE, ZUGLEICH EIN WEITERER BEITRAG ZOR LEGENDENPROLOGFRAGE.

\section{II.}

a) Die reichsfarben.

In der Knightes Tale, A $975 \mathrm{ff}$, heilst es:

The rede statue of Mars with spere and targe

So shyneth in his white banner large,

That alle the feeldes glyteren up and down, And by his banner born is his penoun

Of gold ful riche, in which ther was $y$-bete

The Minotaur, which that he slough in Crete.

Teseide I. 3 ist von dem Marte rubicondo die rede, auch hat Skeat (note zu Knightes Tale, v. 975 ff.) klargelegt, 'thàt some of this description was suggested by the Thebais XII 665-671'; doch zeigt der ganze passus der quelle sehr wenig ahnlichkeit mit der darstellung Chaucers. Sehr wichtig und beachtenswert ist hierbei, dals in der Thebais ${ }^{1)}$ der Minota ur auf dem schilde des Theseus, nicht, wie hier, auf dem penoun des königs erscheint. Die beschreibung des kriegers Theseus, seines banners und seines penoun ist nach den eingehenden untersuchungen von Cummings, 'The Indebtedness of Chaucer to the Italian works of Boccaccio',2) s. 134 unten,

1) Thebris 12,665-672 (Skeat, note zn v. 975).

2) Siehe meine rezension im Mai-heft des Anglia-Beiblatts 1918. 
LANGE, DIE FARHEN KONIG RICHAKDS II VON KTGLATD. 353

als ein neues element in der Palamon und Arcite-geschichte za betrachten.

Wie aber, fragen wir uns, haben wir diese fiktion unseres dichters zu erklären? Ich halte es nicht für ausgeschlossen, dals Chancer in den versen A $975 \mathrm{ff}$. das feldzeichen des englischen reiches, das dem wappen des heiligen Georg entnommene rote kreuz auf weilsem grunde, vor augen hatte; $\left.{ }^{1}\right)$ denn, wenn auch das rot für den krieg\&gott Mars selbstverständlich ist, so dürfte doch die weilse farbe des banners schwerlich rein zufällig sein.

Wie der name des Minotaurs, des ungeheuers, das in der schilderung Chaucers auf dem penoun des königs prangt, so war die abbildung des heiligen Georg, in ritterlicher rüstung auf einem schimmel sitzend und mit der lanze einen drachen durchbohrend, unserm dichter sicherlich nicht unbekannt. Der kriegsgott Mars mit speer und tartsche würde demnach dem mit der lanze bewaffneten St. Georg entsprechen, whhrend der von Thesens erschlagene Minotaur die vorstellung des vom heiligen Georg getöteten drachens wachruft.

In den statuten des hosenbandordens, den konnig Eduard III von England um das jahr 1344 gründete, heilst es, dals er ihn zur ehre gottes, der heiligen jungfran und des heiligen märtyrers Georg, des schutzpatrons Englands, gestiftet habe, und unter den insignien des ordens finden wir the Collar und the George: "The latter is a pendant from the former and is a figure of St. George on his charger, in the act of piercing the dragon with his lance" (Nason, Heralds and Heraldry in Jonson's Plays, s. 55).

In der art, wie die erzăhlung des ritters das banner des Theseus mit dem feldzeichen des englischen reiches, den alten gott Mars mit dem heiligen Georg gewissermafsen identifiziert, erkennen wir die geniale kunst unseres dichters, seine schilderungen, mögen sie mitunter auch noch so skizzenhaft sein, zur erhöhung ihrer lebenswahrheit möglichst der wirklichkeit

1) "The Standard, the third variety of early heraldic Flags, which first appears about the middle of the fourteenth century. This flag is of ample proportions, and great length, but its sire varies with the owner's rank. Next to the staff the red cross on a silver field of St. George is blasomed." (Boutell, English Heraldry, 8. 259.)

Anglien N. F. XXX. 
anzupassen, wie das bereits von verschiedenen seiten ausgeführt worden ist (siehe hierzu vor allem Emil Meyer, Die Charakterzeichnung bei Chaucer, Morsbachs Studien, XLV'III).

Was insbesondere die behandlung der italienischen quelle in der Knightes Tale betrifft, so hat Cummings a. a. o. zweifellos das richtige getroffen, wenn er s. 146 meint, dafs "Chaucer's greatest contribution to the story of Palamon and Arcite is this new atmosphere of realism".

\section{b) Livreefarben.}

Auch im legendenprolog hat Chaucer in der beschreibung des liebesgottes und seiner quene ein gemälde entworfen, za dem ihm die wirklichkeit ihre farben lieh. Indem er, wie ich zuerst in einem artikel vom August 1915 "Zur Datierung des Gg-Prologs zu Chaucers Legende von den guten Frauen" in dieser zeitschrift nachgewiesen habe, den liebesgott mit den heraldischen abzeichen seines königs schmückt, hat er der geschichtlichen gestalt Richards II intime, persönliche züge abgelauscht.

Hierzu kommt noch ein weiterer gesichtspunkt. In beiden fassungen des legendenprologs ist der liebesgott in grün gekleidet:

Y-clothed was this mighty god of Love In silke, enbrouded ful of grene greves.

(F 226,7 = Gg. 158/9.)

Sicherlich hat den dichter hier eine ganz bestimmte absicht geleitet: es liegt eine klare beziehung zu der livreefarbe (grün) kőnig Richards vor, entsprechend der tatsache, dals ja auch, wie oben, teil I, s. 142, gezeigt, in dem porträt Richards II in der Westminster Abtei der könig in 'a vest of green' erscheint. Aber auch die königin ist clad in real habite grene ${ }^{1}$ ) (F 213/4, entsp. Gg 145/6). Da beide male, sowohl F 226 und $\mathrm{Gg}$ 158, als auch F 214 und $\mathrm{Gg}$ 146, yclothed, bezw. clothed oder clad steht, ergibt sich eine sehr deutliche parallele.

Um den von Lowes und zuletzt noch von Langhans, "Der

1) An der von Lowes, Publ. Mod. Lang. Assoc. XIX 644 zitierten parallelstelle der franzбsischen quelle 'leur abit estoient royal' ist von einem grünen habite nicht die rede. 
Prolog zu Chancers Legende von guten Franen", Anglia, band XLI. Neue Folge bd. XXIX. 1. heft, s. 180/1, geäufserten bedenken beztiglich der identifikation der daisy and Alcestis mit der königin Anna entgegenzutreten, dürfte es sich empfehlen, die gedanken des F-prologs, auf die es hier in der hauptsache ankommt, dem genanen wortlante nach $\mathrm{zu}$ betrachten. "Die daisy ist die königin der blumen (v. 185). Aber wenn ich diese blume so sehr preise (v. 189), so will ich mich damit doch nicht (wie es scheinen könnte) in den (bekannten) streit $\mathrm{zwischen} \mathrm{"flour} \mathrm{und} \mathrm{leef"} \mathrm{einmischen.} \mathrm{Ich}$ gehorre keiner der beiden parteien an (v. 193). Mir ist dieser streit gleichgültig (v. 191 ff.). Denn für mich handelt es sich un etwas ganz anderes, mein gedicht (v. 195) hat einen anderen inhalt (nach Gg v. 78 einen anderen zweck, eine andere absicht - entent of myn labour), der schon lange feststand, ehe der streit um blume and blatt begonnen wurde." (Morsbach.)

Nicht die vorzüge von blume und blatt, nicht die damen der Flora und Diana will Chaucer preisen, die das haupt ihrer verehrer entweder mit dem blumenschapel oder mit dem blatt (des lorbeers, der der Diana geweiht war) schmücken [nicht die knights of the flower, die grün tragen, oder die in weifs gekleideten knights of the leaf verherrlichen] - sein lied gilt dem uralten thema von liebe und trene; es ist das lied von "treuer liebe" (daisy, treulieb). Die quene ist wie die daisy 1) 'crowned with white and clothed al in grene', was F 242 und F 303 betont wird. Diese farben der daisy und quene involvieren die liebe (grün) und treue (weils) und bilden (mit dem weifs) den übergang zur (trenen, tugendhaften) Alcestis, F 432, was besonders deutlich wird F 296 ff.:

Heel and honour

To trouthe of womanhede, and to this flour

That bereth our alder pris in figurynge. ${ }^{2}$ )

Hire white corowne beryth the witnessynge.

1) Dafs der dichter die daisy mit der quene identifiziert, geht klar hervor ans $F 216 \mathrm{ff}$. und vor allem F 223/4.

2) Macaulay, Modern Language Review, IV, s. 19 widerspricht der Skeat'schen erklärung dieser stelle: "that bears away the prize from all of us all in external beanty or figure" und sagt mit recht: "This I am 
So verschmelzen daisy und Alcestis dem dichter als identifikation der kőnigin. Auf die frage, wer diese kőnigin ist, lautet die offene antwort Chaucers: Alcestis, die "wohl geeignet war, als repräsentantin weiblicher tugend und wärde za fungieren und die rolle der Venus 1) als konigin der liebe in ihrer christlich-ritterlichen anfassung zu übernehmen" (Düring, Chaucer-Übersetzung, s. 257). Nun nennt F 316 der god of love die daisy 'myn owne flour'. Sie wird also anfgefafst als die kőnigliche blume, die blume des kőnigs (god of love $=$ Richard), symbolisch für die königin. Uud diese königin trägt die persőulichen farben Richards II, grün und weifs, und ist wie der könig selbst in grän gekleidet. Da sonst in der literatur die farbe der liebe gewöhnlich nicht grü $n$ und die der treue nicht weifs ist, dies aber die farben Richards sind, und ferner, da der gott der liebe bei Chaucer ein grün gesticktes gewand und die königin eine weifse (blumen-) krone und ein grünes gewand hat, so scheint mir das ein sicherer beweis, dafs unter dem "god of love" und seiner "noble quene" Richard II und die königin Anna zu verstehen sind. $\left.{ }^{2}\right)$ Das gedicht, insbesondere der prolog, war nach Tatlock, Development, s. 107, jedenfalls bestimmt, bei hofe vorgelesen zu werden, wo damen und herren des gefolges in den farben Richards erschienen. Das gibt dem ganzen den realistischen hintergrund.

Man darf wohl behaupten, dafs diese aufassung zugleich der dichtung grölseren wert und besonderen reiz verleiht.

sure is wrong. It means rather 'that displays the glory of us all in a figure or emblem' (Sinnbild). It is not that the daisy surpasses all women in external besuty, but it is an emblem of their spiritual graces, of parity and of truth."

1) Conrt of Love 106 ist Alceste nnder Venus lady and quene.

2) Im zusammenhang mit meinen untersuchungen über den Blume und Blatt-Cultus, die sich ihrem abschlusse nähern, wird die frage der identification des königspaares mit den gestalten des legendenprologs, dem liebesgott einerseits and der daisy-Alcestis andrenseits, noch einmal zu erortern sein.

Berlin-Weissensee, Juni $1918 . \quad$ Hogo Lange. 